\title{
MISOGYNIST DI DALAM HADIS \\ (TELAAH HADIS SUNAN TIRMIDZI DAN IBNU MAJAH, PEREMPUAN SUMBER FITNAH PALING BERBAHAYA)
}

\author{
Nurdin \\ Rufika Sari \\ Penyuluh Agama Madya Kemenag Pekanbaru \\ Email: odhen_mcom@yahoo.com
}

\begin{abstract}
Today fighter for women's rights increasingly critical in addressing every thing related to women. As has been known that the more criticism addressed to the traditions of the Prophet, the Prophet is accused of marginalizing the position of women in the presence of men, the Prophet accused of traditions that hatred of women (misogynist). One tradition that really should be dissected is the source of slander women narrated by Imam Nasa'iy and Ibn Majah. Speculation has grown in interpreting these traditions. As if women become mastermind in every error and problems on this earth. Based on this study proved the hadith Tirmidhi and Ibn Majah valid with narrators tsiqah and mutual acceptance and giving history and sanad and can be used as evidence. The purpose of this tradition is the spouse of women for men can be a test or trial for a man, when can be ignored on other obligations.
\end{abstract}

Keywords: Misogynist, misogynist in hadist, the source of slander

\begin{abstract}
Abstrak: Dewasa ini pejuang hak-hak perempuan semakin kritis dalam menyikapi setiap sesuatu yang berkaitan dengan perempuan. Seperti yang telah diketahui bahwasannya kritikan tersebut lebih banyak ditujukan kepada hadis Nabi, Nabi dituding telah memarjinalkan kedudukan perempuan di hadapan laki-laki, Nabi dituduh telah menyabdakan hadis yang hatred of women (misogynist). Salah satu hadis yang benar-benar harus dibedah adalah perempuan sumber fitnah yang diriwayatkan oleh Imam Nasa'iy dan Ibnu Majah. Berbagai spekulasi telah berkembang dalam menafsirkan hadis tersebut. Seolah-olah perempuan menjadi dalang dalam setiap kesalahan dan permasalahan di muka bumi ini. Berdasarkan penelitian ini terbukti hadis riwayat Tirmidzi dan Ibnu Majah sahih dengan perawi yang Tsiqah dan saling menerima dan memberi riwayat dan muttasil dan dapat dijadikan hujjah. Adapun maksud hadis ini adalah perempuan merupakan pasangan hidup bagi laki-laki dapat menjadi ujian atau fitnah bagi laki-laki, bila dapat melalaikanya pada kewajibanya yang lain.
\end{abstract}

Kata Kunci: Misogynist, misogynist dalam hadis, sumber fitnah

\section{PENDAHULUAN}

Sebagai sumber kedua syariat Islam, Hadis memiliki fungsi penting dalam system sumber ajaran Islam, terutama dalam memberikan penjelasan dan pemahaman terhadap al-Qur'an.
Tanpa Hadis, petunjuk-petunjuk yang terdapat dalam al-Qur'an tidak bisa diserap dan dipahami secara komperhensif. Mengingat kedudukan Hadis sebagai sumber ajaran Islam yang 
sangat penting, akan tetapi dari aspek datangnya, ia bersifat zhanniy maka para ulama merasa perlu melakukan penelitian dan pengkajian yang mendalam mengenai keberadaan Hadis-Hadis Nabi tersebut. ${ }^{1} \mathrm{Hal}$ tersebut menjadi celah bagi orang-orang yang tidak menyukai keberadaan Islam dewasa ini, dengan menyerang Hadis dari berbagai penjuru baik itu dari segi sanad maupun matnnya. Salah satu bukti dari penyerangan tersebut adalah munculnya wacana Misogynist terhadap beberapa Hadis.

Fakta menunjukkan memang ada pandangan yang timpang dan miring terhadap perempuan yang ternyata memakai teks-teks keagamaan, terutama Hadis Nabi, sebagai alat legitimasi. Bahkan banyak Hadis-Hadis yang dijadikan sebagai alat pembenaran untuk memojokkan kaum perempuan atau untuk diberikan label-label yang merendahkan. Reaksi perlawanan lalu muncul dengan membangun teori ada kelompok konspirasi yang sengaja membuat Hadis-Hadis untuk menghina perempuan, atau Hadis Misogynist, seperti termuat dalam berbagai kitab Tafsir yang sudah populer, maupun kitab Hadis dan Syarahnya. ${ }^{2}$

Berangkat dari kenyataan diskriminasi, subordinasi dan marginalisasi terhadap perempuan dalam Islam, Feminis Muslim justru menggunakan piranti keislaman berperspektif keadilan jender untuk mendekonstruksi teks-teks keagamaan dalam usahanya mewujudkan keadilan dan kesetaraan jender dalam Islam. Feminis Muslim ingin menunjukkan bahwa penafsiran keagamaan yang selama ini menghasilkan produk penafsiran yang kurang bersahabat terhadap perempuan ternyata bisa pula dihasilkan dengan model penafsiran baru yang produk penafsirannya bisa bersahabat terhadap perempuan dalam upaya membangun pola relasi laki-laki dan perempuan secara adil dan setara. ${ }^{3}$

Setelah ditelaah ada \pm 10 Hadis yang terindikasi dan dicap sebagai Hadis Misogynist, yang di antaranya adalah Hadis riwayat Bukhari, Muslim, Abu Dawud, al-Nasa'i, al-Tirmidzi, Ibnu Majah, dan Ahmad. Berikut ini contoh Hadis yang terindikasi Misogynist menurut Feminis adalah:

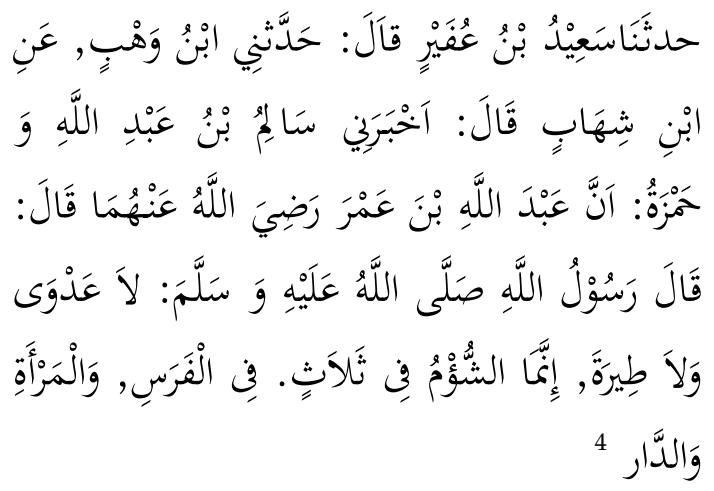

Telah menceritakan kepada kami Sa'id bin 'Ufayr dia berkata: telah menceritakan kepadaku Ibnu Wahb, dari Ibnu Shihab dia berkata: telah mengabarkan kepadaku Salim bin 'Abdullah dan Hamzah, sesungguhnya 'Abdullah bin 'Umar radiyallahu 
Nurdin dan Rufika Sari: Misogynist di dalam Hadis (Telaah Hadis Sunan Tirmidzi dan Ibnu Majah,

'anhuma berkata: Rasulullah sallallahu 'alaihi wa sallam bersabda: "tidak ada keburukan dan kesialan, sesungguhnya kesialan terletak pada tiga hal, pada kuda, perempuan dan tempat tinggal".

Setelah dilacak melalui $M u^{\prime} j a m$ alMufahras li al-Fazh al-Hadits Nabawiy dengan keyword شاءp maka Hadis di atas, diketahui terdapat di Sahih Bukhari di 3 bab yakni masing-masing bab جهاد hal. 47, bab نكاح hal. 17, dan bab 43, 43, dan Sahih Muslim satu bab yakni bab wal. 115-120, dan Sunan Abu Daud ادب bab طب hal. 24, Sunan Tirmidzi bab hal. 58, Sunan Nasa'iy bab_خيـ hal. 5, Ibnu Majjah bab نكـاح hal. 55, alMuwatha' bab استتذذان hal 23, dan Ahmad bin Hanbal jilid 2 hal 8, 36, 115, dan 126.5

$$
\begin{aligned}
& \text { حدثنا احمد بن منيع, اخبرنا هشيم, حدثنا يونس } \\
& \text { و منصور بن زاذان, عن حميد بن هلال عن } \\
& \text { عبدالله بن الصامت قال: سمعت ابا ذر يقول: } \\
& \text { قال رسول الله صلعم: إِذَا صَلَّى الرَّجُحُ وَلَيَْْ بَيْنَ }
\end{aligned}
$$

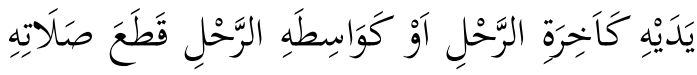

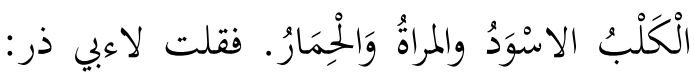

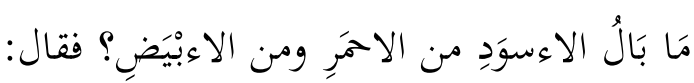

$$
\begin{aligned}
& \text { يابن اخي ساءَلتَنْيْ كَمَا سَاءَلْتُ رسول الله صلعم } \\
& \text { فقال: الكلبُ الاءسْوَدُ شيطان } 6
\end{aligned}
$$

Hadis-hadis tersebut (menurut Feminis) merupakan Hadis yang masih diperselisihkan dan dipertanyakan karena sangat menghina dan melecehkan kedudukan perempuan atau disebut dengan istilah Misogynist. Hadis pertama secara jelas menyamakan perempuan dengan kuda dalam konteks sebagai sumber sebuah kesialan, sedangkan Hadis kedua menyamakan perempuan dengan himar dan anjing dalam konteks batalnya shalat. Kedua Hadis tersebut memberi kesan bahwa perempuan disamakan kedudukannya dengan binatang.

Hadis-Hadis di atas (menurut Feminis) merupakan beberapa contoh tentang muatan Misogynist yang terdapat dalam kitab-kitab Hadis. Karena Hadis-Hadis itu mengandung penghinaan dan pelecehan terhadap perempuan, maka Hadis tersebut mendapat kritikan dari sebagian pemerhati Islam (Feminis muslim). Menurut mereka, Hadis tersebut sangat menghina kedudukan perempuan, karenanya harus ditelaah kebenaran dan pemahamannya.

Hadis lain yang senada dengan Hadis-hadis di atas sangat diskriminatif terhadap perempuanadalahHadis tentang "seorang perempuan akan dikutuk malaikat sampai pagi jika ia enggan memenuhi ajakan suaminya di termpat tidur".

$$
\text { حلح حالثا هناد, حدثنا ملازم بن عمرو, قال:حدثني }
$$


Hadis ini sangat mendeskriditkan perempuan, karena perempuan dikutuk malaikat sampai pagi jika enggan mengikuti kemauan suaminya di tempat tidur, di pihak lain bagi suami tidak ada sanksi apapun jika enggan melayani istri.

Demikian juga halnya mengenai Hadis yang menolak kepemimpinan seorang perempuan "suatu kaum tidak akan pernah bahagia jika dipimpin oleh seorang perempuan".

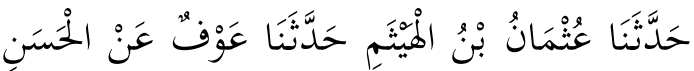
عَنْ أَبِي بَكْرَة قَالَ لَقَدْ نَفَعَنِي اللَّهُ بِكَلِمَةٍة أَيَّامَ

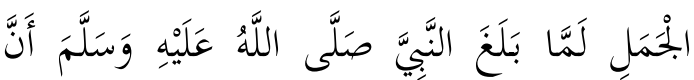

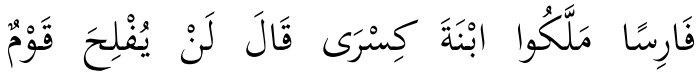

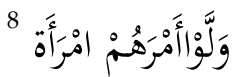

“Tidak akan sukses suatu kaum yang menyerahkan urusannya pada kaum perempuan".

Banyak lagi Hadis-Hadis lain yang terdapat dalam beberapa kitab Hadis yang bermuatan diskriminasi bahkan penghinaan dan kebencian terhadap perempuan. ${ }^{9}$

Permasalahan di atas sangat menarik untuk dikaji, agar tidak terjadi lagi pemahaman yang salah terhadap hadis nabi mengenai perempuan, dan agar tidak ada tudingan miring terhadap perempuan (pemikir misoginis) terhadap hadis Nabi yang berkenaan dengan perempuan. Tujuan terpenting dalam penelitian ini adalah memberikan jalan keluar dan pemahaman yang lebih jelas.

\section{PEMBAHASAN}

\section{Pengertian Misogynist}

Istilah misogini (mysogyny) secara etimologi berasal dari kata misogynia (Yunani) yaitu miso (benci) dan gyne (wanita) yang berarti a hatred of women, yang berkembang menjadi Misoginisme (mysogynism), yang bermakna suatu ideologi yang membenci wanita. ${ }^{10}$ Selain itu istilah misogini dianalogikan berasal dari istilah yang berasal dari bahasa Inggris misogyny yang mempunyai arti yang sama yakni kebencian terhadap perempuan. Kamus Ilmiah Populer menyebutkan, terdapat tiga ungkapan berkaitan dengan istilah tersebut, yaitu misogin artinya benci akan perempuan, misogini artinya perasaan benci akan perempuan, misoginis artinya laki-laki yang benci pada perempuan. ${ }^{11}$

Secara terminologi istilah misoginis digunakan untuk doktrindoktrin sebuah aliran pemikiran yang secara zahir memojokkan dan merendahkan derajat perempuan. ${ }^{12}$ Anggapan adanya unsur misoginis dalam hadis dipopulerkan oleh seorang aktivis perempuan Fatimah Mernissi melalui bukunya "Women and Islam: An Historical and Theological Enquiry". Dalam bukunya, Fatimah Mernissi ${ }^{13}$ memaparkan sejumlah hadis-hadis yang menurut pandangannya bernada misoginis. 


\section{Sejarah Singkat Munculnya Pemikiran Misogynist}

Istilah misogini berawal dari adanya mitos tentang penciptaan wanita dan keluarnya Adam dari surga ke bumi menjadi sebab munculnya banyak perlakuan kasar dan negatif terhadap wanita. Dalam cerita itu wanita diciptakan untuk melengkapi hasrat Adam dan Adam jatuh ke bumi karena godaan Hawa. Cerita seperti ini melahirkanfaham misoginis (pembencian wanita oleh pria). Faham yang berasal dari ajaran Yahudi-Kristen ini berpengaruh cukup luas di dalam dunia Arab melalui berbagai media, seperti kitab-kitab tafsir dan kitab-kitab Fiqh.

Keberadaan mitos sebagai akar kebencian terhadap kaum wanita juga bisa dilihat dari penjelasan Hyde. Menurut Hyde, dalam diri kaum wanita dilekatkan mitos-mitos yang kurang menguntungkan bagi mereka, antara lain mitos mengenai kejahatan feminin (feminie evil) yang berasal dari tradisi Judeo-Kristen mengenai kejatuhan manusia dari surga karena kesalahan Eva membujuk Adam untuk makan buah dari pohon pengetahuan. Perbuatan ini dianggap sebagai akar dari dosa asal seluruh umat manusia yang disebabkan oleh perbuatan Eva (wanita). Di Yunani dikenal mitos mengenai Pandora, manusia wanita pertama di dunia, yang membuka kotak terlarang sehingga menyebarlah semua benih kejahatan di atas muka bumi ini.
Di Cina di kenal dua kekuatan Yin dan Yang yang berhubungan dengan aspek feminin dan maskulin. Yin yang feminin terkait dengan kegelapan, kejahatan, sisi dari alam. Sedang Yang yang maskulin kebalikan dari sifat-sifat tersebut. ${ }^{14}$

Selanjutnya, istilah misogini (misogyny) ini digunakan oleh feminis psikoanalis untuk menyatakan kebencian terhadap wanita (hatred of women) yang berakar pada kemarahan bayi primitif terhadap ibunya karena masyarakat memberikan tugas pengasuhan anak kepada wanita. Tumbuhnya kebencian kaum pria terhadap kaum wanita tersebut bisa ditelusuri dari penjelasan Chodorow mengenai proses perkembangan kepribadian anak laki-laki dan perempuan melalui sosialisasi nilai-nilai jender tertentu.

Pemikiran Chodorow tersebut menunjukkan, bahwa devaluasi kultural dan sosial yang dilakukan oleh anak laki-laki tersebut mengarahkannya pada perilaku untuk merendahkan dan tidak menyukai segala sesuatu yang berbau wanita atau feminim yang diterimanya di masa-masa awal kehadirannya di dunia ini. Pada tahap pembentukan identitas dirinya sebagai laki-laki itu ia mempelajari bahwa untuk bisa diterima di dunia luar, ia harus menyesuaikan dirinya dengan nilai-nilai dominan yang hidup disana yaitu nilai-nilai yang bersifat patriarkis. Untuk bisa menjadi anggota dunia pria itu, anak laki-laki 
berusaha mengenyahkan semua sifatsifat feminim yang ada di dalam dirinya. Kebencian anak pada sifat-sifat feminim timbul karena sifat-sifat itu ternyata cukup kuat tertanam dalam dirinya sebagai konsekwensi dari masa tidak berdayanya dulu ketika ia sangat bergantung pada ibunya. Demikianlah kiranya munculnya sifat benci kaum pria terhadap kaum wanita. ${ }^{15}$

Lebih lanjut, Susan Brown Miller dan Andrea Dworkin mendeskripsikan hubungan antara misogini dan kekerasan seksual laki-laki terhadap perempuan dan Susan Griffin mendeskripsikan kaitan selanjutnya antara ciri-ciri misogini dan militerisme. Adrienne Rich telah menggambarkan misogini sebagai kekerasan dan serangan terhadap perempuan yang dianggap normal, institusional dan terorganisir. ${ }^{16}$

Dalam pandangan Daly (1985), adanya kasta seksual (sexual caste) yang diterima oleh satu kelompok manusia sejak kelahirannya di masyarakat telah menyebabkan terjadinya kekerasan jender. Keberadaan kasta ini telah membatasiakses kelompokitu terhadap barang-barang, pelayanan, prestise, dan segala sesuatu yang berkaitan dengan aspek fisik dan mentalnya. Semua itu harus diterima hanya karena kebetulan kelompok itu dilahirkan berjenis kelamin wanita. Sistem kasta seksual ini telah melahirkan eksploitasi dan penidasan terhadap kaum wanita secara berkelanjutan dikarenakan kaum pria melalui berbagai sarana sosialisasi ideologi patriarki yang ada, salah satunya adalah melalui agama, selalu mengukuhkan sistem kasta tersebut sebagai "rencana Tuhan". Dalam hal ini adalah Tuhan Ayah (God of Father) yaitu sosok Tuhan yang represensasinya terdapat pada manusia berjenis kelamin laki-laki. Bagi Daly, hal semacam itu menunjukkan adanya kebencian terhadap wanita (misoginy) yang telah merasuki kehidupan religius Gereja Judeo-Kristiani. Pendapat tokoh-tokoh semacam Tertulliaus, Agustinus, Thomas Aquinas, Martin Luther, John Knox, ataupun Paus Pius XII menunjukkan bagaimana kebencian terhadap wanita itu muncul dari kalangan religius.

Selain itu juga nilai-nilai teologis kristiani yang misoginistik dari Agustinus yang melihat wanita sebagai iblis penggoda yang telah menyebabkan manusia menderita dosa asal sejak kejatuhan Adam dari surga karena bujukan hawa. Tafsir teologis misoginistik juga terjadi dalam Islam masa kekhalifahan Abbasiyah (7501258) yang menempatkan kedudukan kaum wanita Muslim sama jeleknya dengan rekan-rekan mereka di kalangan masyarakat Yahudi dan Kristen.

Menurut Holland, dalam keseluruhan sejarah, misogini mengejewantahkan dirinya dalam beragam cara pada beragam waktu 
yang berbeda. Bahkan, apa yang disebut sebagai sejarah sebenarnya semata-mata merupakan kisah patriarki, dengan misogini sebagai ideologinya, sebuah sistem keyakinan dan gagasan yang bertujuan untuk menjelaskan dominasi pria atas wanita. Manifestasi misogini tersebut terjadi melalui proses dehumanisasi ganda (dual process of dehumanization), meninggikan dan merendahkan derajat wanita. ${ }^{17}$

\section{Takhrij Hadis Misogynist Sunan Tirmidzi}

a. Lafadz Hadis Perempuan Sumber Fitnah Riwayat Sunan Tirmidzi

Menurut informasi $\mathrm{Mu}^{\prime} \mathrm{jam}^{18}$ melalui lafadz فن hadis ini diriwayatkan oleh Tirmidzi kitab Adab bab. 31, dengan lafadz:

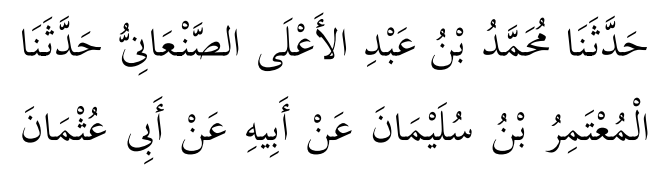

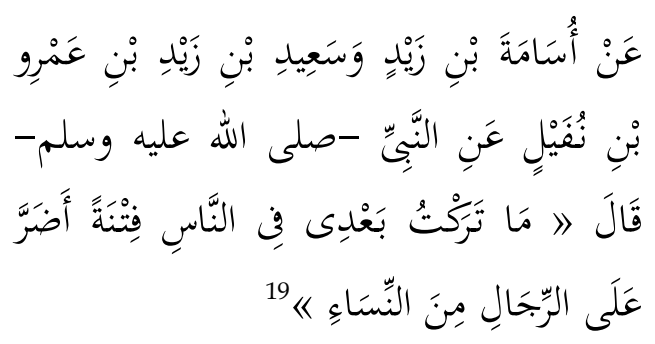

Telah menceritakan kepada kami Muhammad bin 'Abdi al-A'la asShan'aniy, telah menceritakan kepada kami al-Mu'tamiru bin Sulaiman dari ayahanya dari Abiy 'Utsman dari Usamah bin Zayd dan Sa'id bin Zayd bin 'Amru bin Nufayl dari Nabi Sallallahu 'Alaihi wa sallam bersabda: "aku tidak meninggalkan fitnah kepada manusia sesudahku yang lebih berbahaya bagi kaum laki-laki selain kaum wanita".

Adapun rangkaian (i'tibar) sanadnya adalah sebagai berikut: 
marwah, Vol. XIII No. 2 Desember Th. 2014

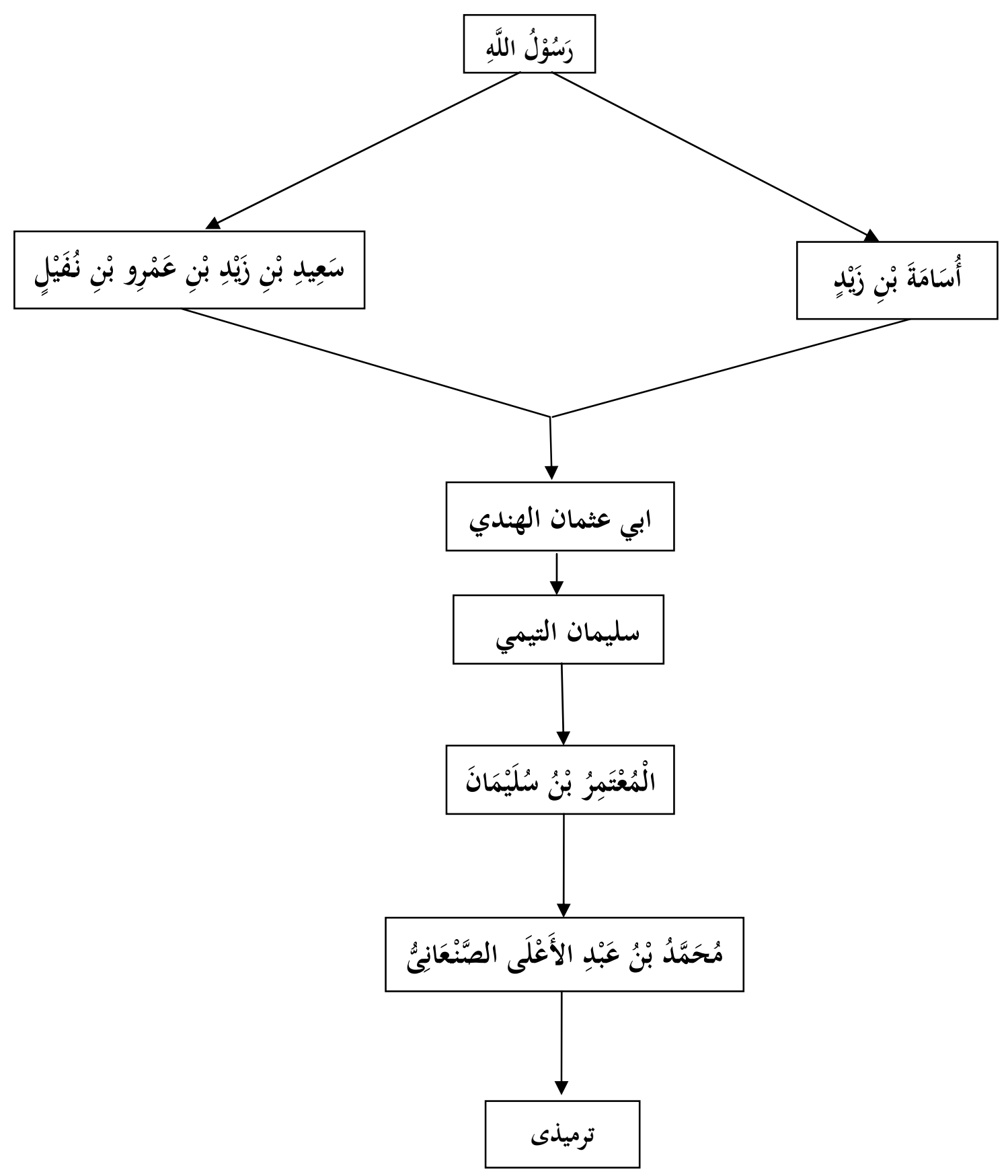


Nurdin dan Rufika Sari: Misogynist di dalam Hadis (Telaah Hadis Sunan Tirmidzi dan Ibnu Majah, Perempuan Sumber Fitnah Paling Berbahaya)

a. Tingkatan Perawi

Sebelum menjelaskan biografi para perawi, maka akan dijelaskan dahulu tingkatan dan urutan sanad para perawi melalui jalur Tirmidzi, sebagai berikut:

\begin{tabular}{|c|l|l|l}
\hline No & Nama Perawi & Urutan Perawi & $\begin{array}{l}\text { Urutan } \\
\text { Sanad }\end{array}$ \\
\hline 1 & $\begin{array}{l}\text { Sa'id bin Zaid bin 'Amru bin Nufail al- } \\
\text { Qurasyiyyu (W.: 51) }\end{array}$ & Perawi I & Sanad V \\
\hline 2 & $\begin{array}{l}\text { Usamah bin Zaid bin Haritsah bin Syarahil al- } \\
\text { Kalbiyyu (W. 54) }\end{array}$ & Perawi I & Sanad V \\
\hline 3 & $\begin{array}{l}\text { Abu 'Utsman an-Hindiy, namanya } \\
\text { 'Abdurrahman bin Maal' bin 'Amru bin 'Adiy } \\
\text { bin Wahb bin Rabi' ah bin Sa'd bin Judziymah } \\
\text { (W.: 130) }\end{array}$ & Perawi II & Sanad IV \\
\hline 4 & $\begin{array}{l}\text { Sulaiman bin Tharkhan at-Taymiy, ayah } \\
\text { Mu'tamiru (W. :143) }\end{array}$ & Perawi III & Sanad III \\
\hline 5 & $\begin{array}{l}\text { Mu'tamiru bin Sulaiman bin Tharkhan at- } \\
\text { Taymiyyu (W. 187) }\end{array}$ & Perawi IV & Sanad II \\
\hline 6 & $\begin{array}{l}\text { Muhammad bin 'Abdil A'la as-Shan'aniy al- } \\
\text { Qaysiy (W. :245) }\end{array}$ & $\begin{array}{l}\text { Perawi V } \\
\text { Tirmidzi (W. 279) }\end{array}$ & Perawi VI \\
\hline 7 & Hadis \\
\hline
\end{tabular}

b. Biografi Sanad

Bila dilihat darijalur Tirmidzi, maka rangkaian transmiter yang terlihat dalam periwayatan hadis tersebut adalah: Tirmidzi menerima dari Muhammad bin 'Abdil A'la asShan'aniy al-Qaysiy, ia menerima dari Mu'tamiru bin Sulaiman bin Tharkhan at-Taymiyyu, yang ia terima dari Sulaiman bin Tharkhan
at-Taymiy, ayah Mu'tamiru, ia menerima dari Abu 'Utsman anNahdiy, namanya 'Abdurrahman bin Maal, ia menerima dari Usamah bin Zaid bin Haritsah bin Syarahil al-Kalbiyyu, ia menerima dari Sa'id bin Zaid bin 'Amru bin Nufail alQurasyiyyu, yang ia terima dari Rasulullah SAW. Bila diuraikan dapat dijelaskan sebagai berikut: 


\begin{tabular}{|c|c|c|c|c|c|}
\hline No & Nama Perawi & L./W. & Guru & Murid & Jarh wa Ta'dil \\
\hline 1 & $\begin{array}{l}\text { Sa'id bin Zaid bin } \\
\text { 'Amru bin Nufail } \\
\text { al-Qurasyiyyu }\end{array}$ & W.: 51 & $\begin{array}{l}\text { Nabi } \\
\text { Sallallahu } \\
\text { ‘alaihi wa } \\
\text { sallam }\end{array}$ & $\begin{array}{l}\text { Humaid bin } \\
\text { 'Abdirrahman } \\
\text { bin 'Auf, } \\
\text { Riyah bin } \\
\text { Harits an- } \\
\text { Nakha'iy, Abu } \\
\text { ‘Utsman an- } \\
\text { Nahdiy, dan } \\
\text { lain-lain }\end{array}$ & Al-Waqidiy: Tsabit ${ }^{21}$ \\
\hline 2 & $\begin{array}{l}\text { Usamah bin Zaid } \\
\text { bin Haritsah bin } \\
\text { Syarahil al- } \\
\text { Kalbiyyu }\end{array}$ & W. 54 & $\begin{array}{l}\text { Nabi } \\
\text { sallallahu } \\
\text { 'alaihi wa } \\
\text { sallam, Bilal } \\
\text { bin Rabah, dan } \\
\text { ayahnya Zaid } \\
\text { bin Haritsah, } \\
\text { dll }\end{array}$ & $\begin{array}{l}\text { ‘Utsman bin } \\
\text { ‘Affan, } \\
\text { Ibrahim bin } \\
\text { Sa'd bin abi } \\
\text { Waqash, Abu } \\
\text { ‘Utsman an- } \\
\text { Nahdiy, Abu } \\
\text { Hurayrah, dll }\end{array}$ & $\begin{array}{l}\text { Mughirah dari } \\
\text { Sya'biyyi, dari } \\
\text { 'Aisyah, Rasulullah } \\
\text { bersabda: } \\
\text { barangsiapa yang } \\
\text { mencintai Allah dan } \\
\text { Rasul, maka cintailah } \\
\text { Usamah bin Zaid } 22\end{array}$ \\
\hline 3 & $\begin{array}{l}\text { Abu 'Utsman an- } \\
\text { Hindiy, namanya } \\
\text { 'Abdurrahman } \\
\text { bin Maal'23 bin } \\
\text { 'Amru bin 'Adiy } \\
\text { bin Wahb bin } \\
\text { Rabi'ah bin Sa'd } \\
\text { bin Judziymah²4 }\end{array}$ & $\begin{array}{l}\text { W.: } \\
130^{25}\end{array}$ & $\begin{array}{l}\text { 'Abdullah bin } \\
\text { Mas'ud, }{ }^{26} \\
\text { Ubay bin } \\
\text { Ka'ab, } \\
\text { Usamah bin } \\
\text { Zaid, }{ }^{27} \text { dll }\end{array}$ & $\begin{array}{l}\text { Sulaiman at- } \\
\text { Taymiy, }{ }^{28} \\
\text { Humayd at- } \\
\text { Thawayl, } \\
\text { Hannan al- } \\
\text { Asadiyyu }{ }^{29} \text { dll }\end{array}$ & $\begin{array}{l}\text { 'Abdurrahman bin } \\
\text { Abiy Hatim: Tsiqah, } \\
\text { Abu Zur'ah dari } \\
\text { ayah ‘Utsman an- } \\
\text { Nahdiy: Tsiqah, } \\
\text { Nasa'iy dan } \\
\text { 'Abdirrahman bin } \\
\text { Yusuf bin Khirasy: } \\
\text { Tsiqah } 30\end{array}$ \\
\hline 4 & $\begin{array}{l}\text { Sulaiman bin } \\
\text { Tharkhan at- } \\
\text { Taymiy, ayah } \\
\text { Mu'tamiru }\end{array}$ & $\begin{array}{l}\text { W. } \\
: 143 \\
\text { Bashra } \\
\text { h } \\
\text { Dzulq } \\
\text { a'dah }\end{array}$ & $\begin{array}{l}\text { Aslam bin } \\
\text { 'ijliy, Sulaiman } \\
\text { al-A'masy, } \\
\text { Abu 'Utsman } \\
\text { an-Nahdiy, dll }\end{array}$ & $\begin{array}{l}\text { Ibrahim bin } \\
\text { Sa'd, Isma'il } \\
\text { bin 'ulayyah, } \\
\text { Hammad bin } \\
\text { Salamah, } \\
\text { Mu'tamiru } \\
\text { bin Sulayman, } \\
\text { dll }\end{array}$ & $\begin{array}{l}\text { 'Abdullah bin } \\
\text { Ahmad bin Hanbal } \\
\text { dari ayahnya: Tsiqah, } \\
\text { Ishaq bin Manshur } \\
\text { dari Yahya bin Mu'in } \\
\text { dan Nasa'iy: Tsiqah, } \\
\text { Ahmad bin 'Abdillah } \\
\text { 'Ijliy: Tsiqah, } \\
\text { Muhammad bin } \\
\text { Sa'd: Tsiqah } 31\end{array}$ \\
\hline 5 & $\begin{array}{l}\text { Mu'tamiru bin } \\
\text { Sulaiman bin } \\
\text { Tharkhan at- } \\
\text { Taymiyyu }\end{array}$ & $\begin{array}{l}\text { L.:106 } \\
\text { W. } 187 \\
\text { di } \\
\text { Bashra } \\
\text { h }\end{array}$ & $\begin{array}{l}\text { Ibrahim bin } \\
\text { Yazid al- } \\
\text { Khuwziy, } \\
\text { As'ats bin } \\
\text { 'Abdul Malik, }\end{array}$ & $\begin{array}{l}\text { Ahmad bin } \\
\text { Hanbal, } \\
\text { Humaid bin } \\
\text { Mas'adah as- } \\
\text { Samiyyu, }\end{array}$ & $\begin{array}{l}\text { Yahya bin Ma'in : } \\
\text { Tsiqah, Muhammad } \\
\text { bin Sa'd: Tsiqah }{ }^{32}\end{array}$ \\
\hline
\end{tabular}


Nurdin dan Rufika Sari: Misogynist di dalam Hadis (Telaah Hadis Sunan Tirmidzi dan Ibnu Majah, Perempuan Sumber Fitnah Paling Berbahaya)

\begin{tabular}{|c|c|c|c|c|c|}
\hline & & & $\begin{array}{l}\text { Sulaiman bin } \\
\text { Tharkhan at- } \\
\text { Taymiy, dll }\end{array}$ & $\begin{array}{l}\text { Yunus bin } \\
\text { Muhammad } \\
\text { bin 'Abdil } \\
\text { A'la as- } \\
\text { Shan'aniy al- } \\
\text { Qaysiy, dll }\end{array}$ & \\
\hline 6 & $\begin{array}{l}\text { Muhammad bin } \\
\text { 'Abdil A'la as- } \\
\text { Shan'aniy al- } \\
\text { Qaysiy }\end{array}$ & $\begin{array}{l}\text { W. } \\
: 245 \text { di } \\
\text { Bashra } \\
\text { h }\end{array}$ & $\begin{array}{l}\text { Ismail bin } \\
\text { 'Ulayyah, } \\
\text { Mu'tamir bin } \\
\text { Sulaiman, Abi } \\
\text { Bakr bin } \\
\text { 'Ayyas, dll }\end{array}$ & $\begin{array}{l}\text { Abu Daud, } \\
\text { Muhammad } \\
\text { bin Ishaq ats- } \\
\text { Tsaqafiy as- } \\
\text { Sarraj, Hilal } \\
\text { bin bin al- } \\
\text { 'Alaa ar- } \\
\text { Raqiyyu, dll }\end{array}$ & $\begin{array}{l}\text { Abu Zur'ah dan Abu } \\
\text { Hatim: Tsiqah, Ibnu } \\
\text { Hibban: Tsiqah }{ }^{32}\end{array}$ \\
\hline
\end{tabular}

- Untuk guru dan murid hanya disebutkan tiga (3) saja di antara guru dan murid perawi yang begitu banyak jumlahnya.

Dengan memperhatikan setiap rangkaian masing-masing sanad hadis di atas, baik ditinjau dari masa hidup, ataupun penjelasan dari masing-masing sanad bahwa mereka saling memberi dan menerima riwayat, maka dapat disimpulkan bahwa hadis tersebut muttasil dan semua sanadnya Tsiqah, maka kualitas hadis tersebut adalah sahih dan dapat dijadikan hujjah.

\section{Takhrij Hadis Misogynist Sunan Ibnu Majah}

a. Lafadz Hadis Perempuan Sumber Fitnah Riwayat Sunan Ibnu Majah

Menurut informasi $M u^{\prime} j a m$ pula, hadis ini diriwayatkan oleh Ibnu Majah kitab Fitan bab. 19, dengan lafadz:

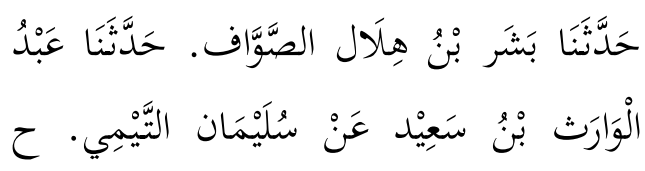

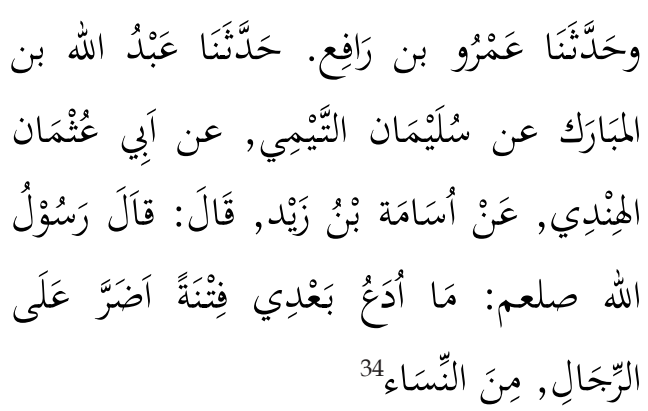

Telah menceritakan kepada kami Basyr bin Hilal as-Shawwaf telah menceritakan kami 'Abdu al-Warats bin Sa'id dari Sulaiman at-Taymiy. Dan Telah menceritakan kepada kami 'Amru bin Rafi' telah menceritakan kepada kami 'Abdullah bin al-Mubarak dari Sulaiman at-Taymiy dari Abi 'Utsman al-Hindiy dari Usamah bin Zayd ia berkata, Rasulullah sallallahu 'alaihi wa sallam bersabda: "tidaklah aku tinggalkan sesudahku fitnah yang lebih berbahaya bagi kaum laki-laki selain kaum wanita". 
Adapun rangkaian (i'tibar) sanadnya adalah sebagai berikut:

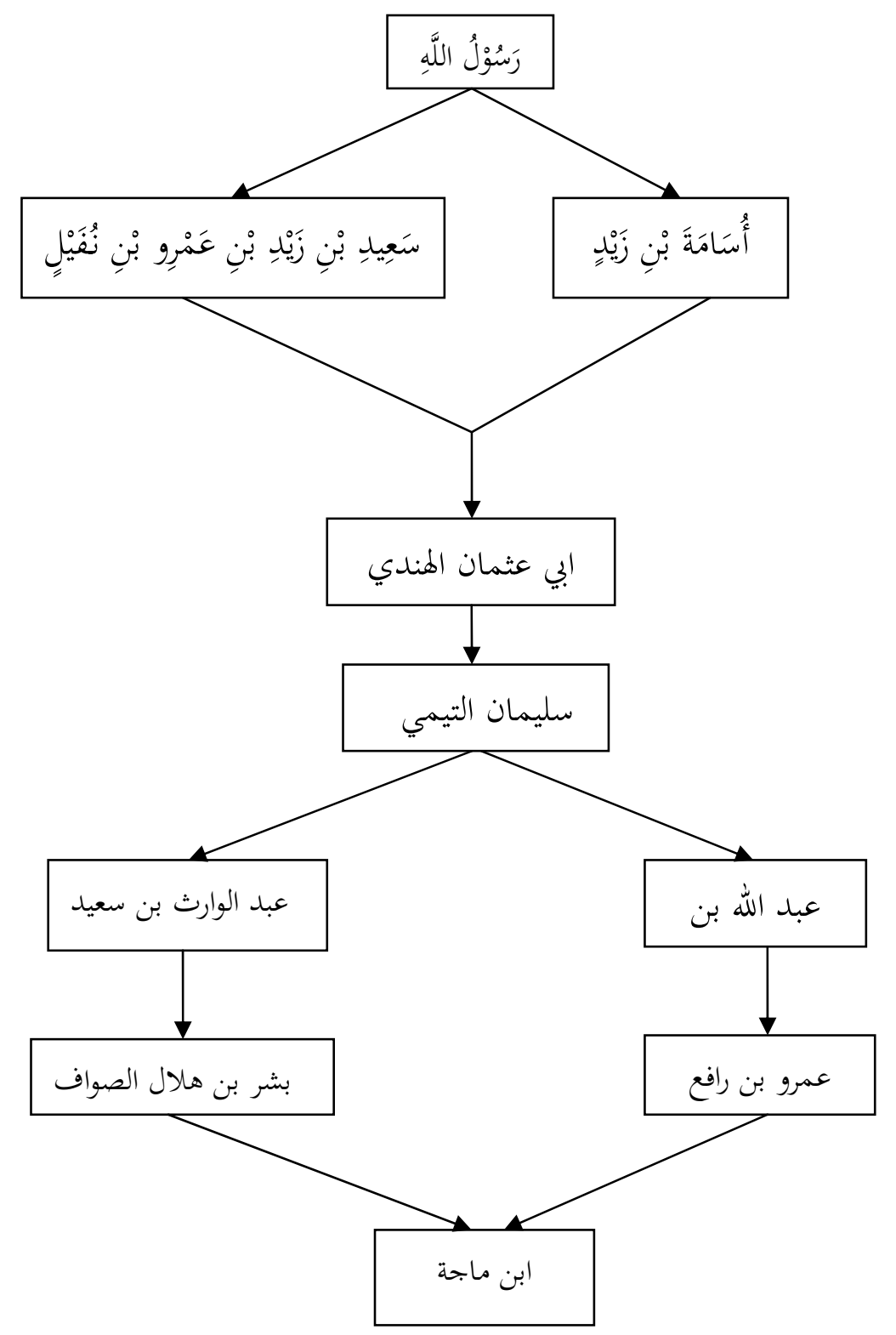

a. Tingkatan Perawi

Sebelum menjelaskan biografi para perawi, maka akan dijelaskan dahulu tingkatan dan urutan sanad para perawi melalui jalur Tirmidzi, sebagai berikut: 
Nurdin dan Rufika Sari: Misogynist di dalam Hadis (Telaah Hadis Sunan Tirmidzi dan Ibnu Majah, Perempuan Sumber Fitnah Paling Berbahaya)

\begin{tabular}{|c|c|c|c|}
\hline No & Nama Perawi & Urutan Perawi & Urutan Sanad \\
\hline 1 & $\begin{array}{l}\text { Sa'id bin Zaid bin 'Amru bin Nufail al- } \\
\text { Qurasyiyyu (W.: 51) }\end{array}$ & Perawi I & Sanad V \\
\hline 2 & $\begin{array}{l}\text { Usamah bin Zaid bin Haritsah bin } \\
\text { Syarahil al-Kalbiyyu (W. 54) }\end{array}$ & Perawi I & Sanad V \\
\hline 3 & $\begin{array}{l}\text { Abu 'Utsman al-Hindiy, namanya } \\
\text { 'Abdurrahman bin Maal }{ }^{35} \text { bin 'Amru bin } \\
\text { 'Adiy bin Wahb bin Rabi'ah bin Sa'd bin } \\
\text { Judziymah (W.: 130) }\end{array}$ & Perawi II & Sanad IV \\
\hline 4 & $\begin{array}{l}\text { Sulaiman bin Tharkhan at-Taymiy, ayah } \\
\text { Mu'tamiru (W. :143) }\end{array}$ & Perawi III & Sanad III \\
\hline 5 & $\begin{array}{l}\text { Mu'tamiru bin Sulaiman bin Tharkhan at- } \\
\text { Taymiyyu (W. 187) }\end{array}$ & Perawi IV & Sanad II \\
\hline 6 & $\begin{array}{l}\text { Muhammad bin ‘Abdil A'la as-Shan'aniy } \\
\text { al-Qaysiy (W. :245) }\end{array}$ & Perawi V & Sanad I \\
\hline 7 & Ibnu Majah & Perawi VI & Mukharij Hadis \\
\hline
\end{tabular}

b. Biografi Sanad

Bila dilihat dari jalur Ibnu Majah, maka rangkaian transmiter yang terlihat dalam periwayatan hadis tersebut adalah: pada jalur pertama Ibnu Majah menerima dari 'Amru bin Rafi', ia menerima dari 'Abdullah bin al-Mubarak, yang ia terima dari Sulaiman at-Taymiy, ia menerima dari Abi 'Utsman al-
Hindiy, ia menerima dari Usamah bin Zaid yang ia terima dari Rasulullah SAW. sedangkan dari jalur kedua Ibnu Majah menerima dari Basyr bin Hilal ash-Shawwaf, ia menerima dari 'Abdul Warats bin Sa' id, ia menerima dari Sulayman atTaymiy, yang ia terima dari Rasulullah SAW. Bila diuraikan dapat dijelaskan sebagai berikut:

\begin{tabular}{|c|c|c|c|c|c|}
\hline No & Nama Perawi & L./W. & Guru & Murid & Jarh wa Ta'dil \\
\hline 1 & $\begin{array}{l}\text { Usamah bin Zayd } \\
\text { bin Haritsah bin } \\
\text { Syarahi al- } \\
\text { Kalbiyyu }\end{array}$ & W. 54 & $\begin{array}{l}\text { Rasulullah, Bilal } \\
\text { bin Rabbah, dan } \\
\text { Zaid bin } \\
\text { Haritsah }\end{array}$ & $\begin{array}{l}\text { Utsman bin } \\
\text { Affan, Abi } \\
\text { Utsman al- } \\
\text { Hindiy, dan } \\
\text { Abu } \\
\text { Hurairah }\end{array}$ & $\begin{array}{l}\text { Mughirah dari } \\
\text { Sya'biyyi, dari 'Aisyah, } \\
\text { Rasulullah bersabda: } \\
\text { barangsiapa yang } \\
\text { mencintai Allah dan } \\
\text { Rasul, maka cintailah } \\
\text { Usamah bin Zaid³6 }\end{array}$ \\
\hline 2 & $\begin{array}{l}\text { Abi ‘Utsman an- } \\
\text { Hindiy, namanya } \\
\text { 'Abdurrahman } \\
\text { bin Maal'37 bin }^{\text {'Amru bin 'Adiy }} \\
\text { bin Wahb bin }\end{array}$ & $\begin{array}{l}\text { W.: } \\
130^{39}\end{array}$ & $\begin{array}{l}\text { 'Abdullah bin } \\
\text { Mas'ud, } 40 \text { Ubay } \\
\text { bin Ka'ab, } \\
\text { Usamah bin } \\
\text { Zaid, }{ }^{41} \text { dll }\end{array}$ & $\begin{array}{l}\text { Sulaiman } \\
\text { at-Taymiy, } \\
\text { Humayd at- } \\
\text { Thawayl, } \\
\text { Hannan al- } \\
\text { Asadiyyu }\end{array}$ & $\begin{array}{l}\text { 'Abdurrahman bin } \\
\text { Abiy Hatim: Tsiqah, } \\
\text { Abu Zur'ah dari ayah } \\
\text { 'Utsman an-Nahdiy: } \\
\text { Tsiqah, Nasa'iy dan } \\
\text { 'Abdirrahman bin }\end{array}$ \\
\hline
\end{tabular}




\begin{tabular}{|c|c|c|c|c|c|}
\hline & $\begin{array}{l}\text { Rabi'ah bin Sa'd } \\
\text { bin Judziymah }{ }^{38}\end{array}$ & & & dll & $\begin{array}{l}\text { Yusuf bin Khirasy: } \\
\text { Tsiqah }^{42}\end{array}$ \\
\hline 3 & $\begin{array}{l}\text { Sulayman at- } \\
\text { Taymiy }\end{array}$ & $\begin{array}{l}\text { (W. } \\
: 143)\end{array}$ & $\begin{array}{l}\text { Aslam al-'Ijliy, } \\
\text { Abi Utsman an- } \\
\text { Nahdiy, dan } \\
\text { Rumaytsah }\end{array}$ & $\begin{array}{l}\text { 'Abdullah } \\
\text { bin al- } \\
\text { Mubarak, } \\
\text { Sufyan bin } \\
\text { ‘Uyaynah } \\
\text { dan Syu'bah } \\
\text { bin Hajjaj }\end{array}$ & $\begin{array}{l}\text { Rabi' bin Yahya: } \\
\text { Shiddiq, Abdullah bin } \\
\text { Ahmad bin Hanbal: } \\
\text { Tsiqah, Ishaq bin } \\
\text { Manshur: Tsiqah, } \\
\text { Ahmad bin ;Abdullah } \\
\text { al-'Ijliy: Tsiqah, } \\
\text { Muhammad bin Sa'd: } \\
\text { Tsiqah }\end{array}$ \\
\hline 4 & $\begin{array}{l}\text { 'Abdullah bin al- } \\
\text { Mubarak bin } \\
\text { Wadih al- } \\
\text { Handhaliyy }\end{array}$ & $\begin{array}{l}\text { L: } 118, \\
\text { W.: } \\
190\end{array}$ & $\begin{array}{l}\text { Sulaiman at- } \\
\text { Taymiy, } \\
\text { Sulaiman al- } \\
\text { A'masy, dan } \\
\text { Sulaiman bin } \\
\text { Mughirah }\end{array}$ & $\begin{array}{l}\text { 'Amru bin } \\
\text { Rafi' al- } \\
\text { Qazwayniy, } \\
\text { 'Affan bin } \\
\text { Muslim dan } \\
\text { 'Attab bin } \\
\text { Ziyad }\end{array}$ & $\begin{array}{l}\text { Muhammad bin Sa'id: } \\
\text { Tsiqah, Hujjah }\end{array}$ \\
\hline 5 & 'Amru bin Rafi' & $\begin{array}{l}\text { W.: } \\
237\end{array}$ & $\begin{array}{l}\text { ‘Abdullah bin } \\
\text { al-Mubarak, } \\
\text { Ya'qub bin } \\
\text { ‘Abdullah al- } \\
\text { Qumiy, dan } \\
\text { Muhammad bin } \\
\text { 'Ubayd }\end{array}$ & $\begin{array}{l}\text { Ibnu Majah, } \\
\text { Yusuf bin } \\
\text { Hamdan, } \\
\text { danYa'qub } \\
\text { bin Yusuf } \\
\text { al- } \\
\text { Qazwayniy }\end{array}$ & Ibnu Hibban: Tsiqat \\
\hline
\end{tabular}

Pada jalur kedua:

\begin{tabular}{|c|c|c|c|c|c|}
\hline No & Nama Perawi & L./W. & Guru & Murid & Jarh wa Ta'dil \\
\hline 1 & $\begin{array}{l}\text { Sulayman at- } \\
\text { Taymiy }\end{array}$ & $\begin{array}{l}\text { (W. } \\
: 143)\end{array}$ & $\begin{array}{l}\text { Aslam al- } \\
\text { ‘Ijliy, Anas } \\
\text { bin Malik, } \\
\text { dan Abi } \\
\text { ‘Utsman an- } \\
\text { Nahdiy }\end{array}$ & $\begin{array}{l}\text { 'Abdul Warats } \\
\text { bin Sa'id, } \\
\text { 'Imran al- } \\
\text { Qaththan, dan } \\
\text { Muhammad } \\
\text { bin Abiy 'Adiy }\end{array}$ & $\begin{array}{l}\text { Rabi' bin Yahya: } \\
\text { Shiddiq, Abdullah bin } \\
\text { Ahmad bin Hanbal: } \\
\text { Tsiqah, Ishaq bin } \\
\text { Manshur: Tsiqah, } \\
\text { Ahmad bin } \\
\text {;Abdullah al-'Ijliy: } \\
\text { Tsiqah, Muhammad } \\
\text { bin Sa'd: Tsiqah }\end{array}$ \\
\hline 2 & $\begin{array}{l}\text { ‘Abdul Warats } \\
\text { bin Sa'id }\end{array}$ & W.: 84 & $\begin{array}{l}\text { Sulaiman at- } \\
\text { Taymiy, } \\
\text { Dawud bin } \\
\text { Hindiy, dan } \\
\text { Sa'id bin } \\
\text { Jumhan }\end{array}$ & $\begin{array}{l}\text { Basyar bin } \\
\text { Hilal ash- } \\
\text { Shawwaf, } \\
\text { Habban bin } \\
\text { Hillal, dan } \\
\text { Sufyan ats- } \\
\text { Tsauri }\end{array}$ & $\begin{array}{l}\text { Ahmad bin Hanbal: } \\
\text { Asahhu an-Nas, } \\
\text { Yyahya bin Ma'in: } \\
\text { Tsabit, Abu Zur'ah: } \\
\text { Tsiqah, Abu Hatim: } \\
\text { Tsiqah, Shudduq, } \\
\text { Nasaiy: Tsiqah, }\end{array}$ \\
\hline
\end{tabular}


Nurdin dan Rufika Sari: Misogynist di dalam Hadis (Telaah Hadis Sunan Tirmidzi dan Ibnu Majah, Perempuan Sumber Fitnah Paling Berbahaya)

\begin{tabular}{|l|l|l|l|l|l} 
& & & & & $\begin{array}{l}\text { Tsabit, Muhammad } \\
\text { bin Sa'd: Tsiqah } \\
\text { Hujjah43 }\end{array}$ \\
\hline 3 & $\begin{array}{l}\text { Basyr bin Hilal as- } \\
\text { Shawwaf }\end{array}$ & $\begin{array}{l}\text { W.: } \\
247\end{array}$ & $\begin{array}{l}\text { 'Abdul } \\
\text { Warats bin } \\
\text { Sa'id, 'Aliy } \\
\text { bin Musyhir, } \\
\text { dan Yazid } \\
\text { bin Zuray' }\end{array}$ & $\begin{array}{l}\text { Al-Jama'ah } \\
\text { kecuali } \\
\text { Bukhari, } \\
\text { 'Abdan al- } \\
\text { Ahwaziy, } \\
\text { dan'Abbas bin } \\
\text { Abiy Thalib }\end{array}$ & $\begin{array}{l}\text { Natiy: Tsiqah, Abu } \\
\text { Hatiqat }\end{array}$ \\
\hline
\end{tabular}

- Untuk guru dan murid hanya disebutkan tiga (3) saja di antara guru dan murid perawi yang begitu banyak jumlahnya.

Dengan memperhatikan setiap rangkaian masing-masing sanad hadis di atas, baik ditinjau dari masa hidup, ataupun penjelasan dari masing-masing sanad bahwa mereka saling memberi dan menerima riwayat, maka dapat disimpulkan bahwa hadis tersebut muttasil dan semua sanadnya Tsiqah, maka kualitas hadis tersebut adalah sahih dan dapat dijadikan hujjah.

\section{Syarah Hadis}

Hadis tentang Perempuan sumber Fitnah paling berbahaya dilihat didalam Tuhfatul Ahwazi, maksud hadis ini adalah: Kalimat "Ma taraktu Ba'diy: artinya: tidaklah aku tinggalkan, Fitnah: artinya: ujian dan cobaan, jadi perempuan dimaksud disini menjadi ujian dan cobaan bagi laki-laki. AlHadifz mengatakan: sesungguhnya fitnah perempuan lebih dahsyat dari pada fitnah selainnya, dan dia bersaksi dengan perkataan Allah ta' ala: manusia itu dihiasi dengan kecintaan syahwat dari wanita", dan sebagian 'ulama mengatakan: perempuan itu buruk semuanya dan buruk apa yang ada pada dirinya dan tidak ada ruang kosong darinya, dan sesungguhnya mereka kurang akal dan agamanya, mereka membawa laki-laki untuk tunduk terhadap kekurangan akal dan agama dengan menyibukkan mereka kepada urusan yang lain daripada untuk meyibukkan diri ke dalam urusan agama, dan membawa mereka (lakilaki) kepada kecelakaan dengan membawa mereka untuk menyibukkan diri untuk duniawi dan itulah yang dimaksud dengan fitnah dan kerusakan yang dahsyat. ${ }^{44}$

\section{Tanggapan Ulama Kontemporer} Terhadap Hadis Misogynist Sunan Tirmidzi Dan Sunan Ibnu Majah

Menurut Quraish Shihab, adanya hadis yang mengatakan bahwa wanita adalah fitnah, merupakan kesalahan pahaman terhadap hadis tersebut. 
Mereka melupakan suatu masalah yang penting, yaitu bahwa manusia difitnah (diuji) dengan kenikmatan lebih banyak daripada diuji dengan musibah. Allah berfirman:

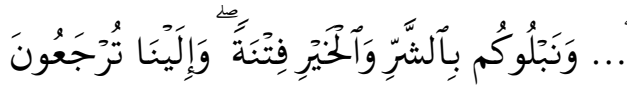

“...Kami akan menguji kamu dengan keburukan dan kebaikan sebagai cobaan (yang sebenar-benarnya)...".(QS: alAnbiya: 35).

Al-Qur'an juga menyebutkan harta dan anak-anak yang merupakan kenikmatan hidup dunia dan perhiasannya sebagai fitnah yang harus diwaspadai, sebagaimana firman Allah:

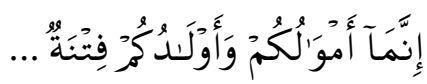

"Sesungguhnya hartamu dan anakanakmu hanyalah cobaan (bagimu)... (QS: at-Thaghabun: 15).

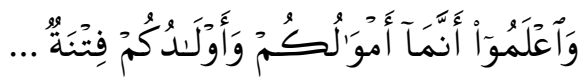

.Dan ketahuilah bahwa hartamu dan anak-anakmu itu hanyalah sebagai cobaan..." (QS: al-Anfaal: 28).

Fitnah harta dan anak-anak itu ialah kadang-kadang harta atau anakanak melalaikan manusia dari kewajiban kepada Tuhannya dan melupakan akhirat. Dalam hal ini Allah berfirman:

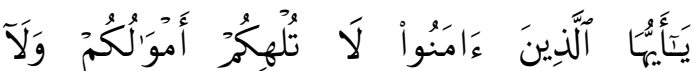

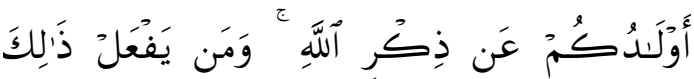

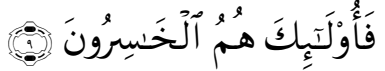

"Hai orang-orang yang beriman, janganlah harta-hartamu dan anakanakmu melalaikan kamu dari mengingat Allah. Barangsiapa yang membuat demikian, maka mereka itulah orang-orang yang rugi". (QS: alMunaafiquun: 9).

Sebagaimana dikhawatirkan manusia akan terfitnah oleh harta dan anak-anak, mereka pun dikhawatirkan terfitnah oleh wanita, terfitnah oleh istriistri mereka yang menghambat dan menghalangi mereka dari perjuangan, dan menyibukkan mereka dengan kepentingan-kepentingan khsusus (pribadi/keluarga) dan melalaikan mereka dari kepentingan-kepentingan umum. Mengenai hal ini al-Qur'an memperingatkan:

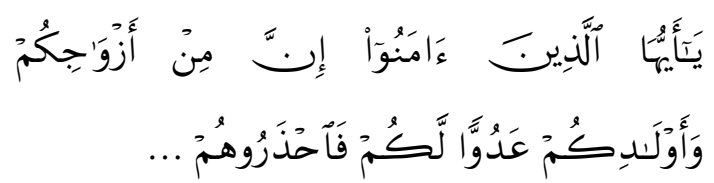

"Haiorang-orang beriman, sesungguhnya di antara istri-istrimu dan anak-anakmu ada yang menjadi musuh bagimu, maka berhati-hatilah kamu terhadap mereka...". (QS: at-Thaghabun: 14).

Ayat ini menjelaskan bahwa pasanganmu dan anak-anakmu adalah musuh bagimu, artinya bila kenikmatan mendapatkan pasangan dan anak-anak, membuat seseorang lalai dengan 
kewajibannya yang lain. Peringatan untuk berhati-hati terhadap perempuan di sini seperti peringatan untuk berhatihati terhadap kenikmatan harta, kemakmuran, dan kesenangan hidup. Dengan demikian hadis Nabi SAW di atas, hanya menyalakan lampu merah bagi pribadi dan masyarakat muslim agar kaki mereka tidak terpeleset dan terjatuh ke dalam jurang tanpa mereka sadari.

Pada akhirnya semua kenikmatan yang diberikan Allah SWT kepada manusia merupakan fitnah atau ujian baginya, bila kenikmatan tersebut tidak membawanya dekat dengan Allah. Baik harta benda, anak-anak maupun pasangan hidupnya (istri bagi suami, suami bagi istri).

\section{KESIMPULAN}

Dari pemaparan masalah serta penyelesain di atas, beberapa kesimpulan yang dapat diungkapkan dari penelitian ini adalah:

1. Hadis riwayat Tirmidzi dan Ibnu Majah, tentang perempuan sumber fitnah paling berbahaya, terbukti hadis tersebut berstatus sahih dan diriwayatkan oleh perawi yang Tsigah dengan sanad yang muttasil sehingga dapat dijadikan hujjah.

2. Telah terbukti bahwa tidak ada hadis Misogynist, yang ada hanyalah kesalahan pahaman terhadap matan hadis tersebut. Pemahaman yang benar bila dihubungkan dengan ayat
al-Qur'an bahwa manusia difitnah (diuji) dengan kenikmatan lebih banyak daripada diuji dengan musibah. Kenikmanatan itu di antaranya adalah harta, anak-anak dan pasangannya.

3. Dikatakan perempuan sebagai sumber fitnah paling berbahaya, bila keberadaan perempuan membuat laki-laki melalaikan kewajiban kepada Allah. Sejalan dengan ayat alQur'an bahwa pasangan dan anakanak mu merupakan ujian atau fitnah bagimu.

\section{Endnotes}

1 Nurhasanah, Perempuan dalam Kitab Sahih Bukhari (Tela'ah Terhadap Hadits "Penolakan Istri atas Ajakan Suami untuk Melakukan Hubungan Sex"), (Pekanbaru, Pusat Studi Wanita UIN Suska Riau, 2006), Jurnal Marwah Volume IV, No. 2, hal. 206

2 Alamsyah, Menyikapi Hadis-Hadis Misoginis, (Laboratorium Studi al-Qur'an), dikutip pada http://menyikapi-hadis-hadis-misoginishtml/ /: 4-06-2013

3 Arif Subhan dkk, Citra Perempuan dalam Islam Pandangan Ormas Kegamaan, (Jakarta, PT. Gramedia Pustaka Utama, 2003), hal. 37

4 Al-Imam al-Hafidz Abi 'Abdillah Muhammad bin Ismail al-Bukhari, (Beirut, Dar Ibn Katsir, 1998), Juz 4, hal. 42

5 A.J Wensick, Mu'jam al-Mufahras li Alfazh alHadits al-Nabawiyah, (Leiden, Maktabah Brill, 1937), hal. 54

6 Abi 'Isa Muhammad bin 'Isa bin Saurah, Sunan Tirmidzi, (Daarul Fikri, t.th), hal. 358

7 Abi ‘lysa Muhammad bin 'Iysa bin Saurah, Ibid., Juz 2, hal. 386

8 Al-Imam al-Hafidz Abi 'Abdillah Muhammad bin Ismail al-Bukhari, Op, Cit, Kitab Fitan, hadis nomor 7099 juz 4, hal. 443

9 Nurhasanah, Op.Cit, hal. 207 Nurhasanah, Op.Cit, hal. 207

10 Sunarto, Televisi, Kekerasan, dan Perempuan, (Jakarta, PT. Kompas Media Nusantara, 2009), hal. 49

11 Muhammad Zaki Syech Abubakar, Pengertian 
Hadis Misoginis (Bagian Pertama), (Lampung, Laboratorium Studi al-Qur'an, 2012), dikutip pada: http:/ / pengertian-hadis-misoginisbagian-pertama, tanggal: 22/05/2013

12 Anita Masduki, Perempuan dalam Islam: Hadith Misoginis versi Fatima Mernissi, (Voa Islam (Voice of al-Islam) Headline News, Bekasi, 2009), diakses pada tanggal 08/012014

13 Fatima Mernissi lahir disebuah harem di Fez, Maroko pada tahun 1940. Saat ini, Mernissi telah memperoleh S2 (master)nya dalam bidang politik dari Universitas Muhammad V di Rabat, Maroko, dan S3/ Ph.D dari Universitas Brandeis di Amerika tahun 1973 Selain itu Fatima Mernissi Mernissi juga belajar di Universitas Sorbone Paris. Karirnya dimulai dari tahun 1974 sebagai dosen dan profesor bidang sosiologi pada Universitas Muhammad V hingga tahun 1980. Kemudian ia melakukan suatu kontrak penelitian pada Marocco's Institut Universitaire de Recherche Scientifique. Buku-buku Fatima Mernissi Mernissi tentang wanita dalam perspektif feminisme telah diterjemahkan ke dalam berbagai bahasa, seperti Inggris, Jerman, Belanda, Jepang dan Indonesia. Karyanya yang terkenal antara lain adalah: (1) Beyond the Veil: Male-Female Dynamics in Modern Muslim Society (1975); (2) Doing Daily Battle (1989); (3) The Veil and the Male Elites (1987); (4) Islam and Democracy: Fear of the Modern World (1992). Karya-karya Mernissi berkisar sekitar hubungan antara ideologi seksual, identitas gender dan organisasi sosial-politik dengan status wanita dalam Islam. Fokus khasnya adalah masyarakat dan kebudayaan Maroko. Lihat dalam: Wilaela, Perempuan-perempuan Haremku (Telaah Pengalaman Perempuan oleh Perempuan dengan Pendekatan Sejarah Peradaban Islam), (Pekanbaru, Pusat Studi Wanita UIN Sultan Syarif Kasim Riau, 2005), Jurnal Marwah, Vol. IV No. 8, hal. 22. Dan Yunahar Ilyas, Hadishadis Misogini Studi Kritis Terhadap Pemikiran Fatima Mernissi tentang Hadis, Tripod, dalam: http://hadis-hadismisoginistudi-kritis-terhadap-pemikiran-fatimamernissi-tentang-hadis-html, dikutip pada tanggal: 22-01-2014

14 London School Beyond Borders: Communication Modernit \& History, (STIKOM The London School of Public Relations, Jakarta,The First LSPR Communication Research Conference 2010), hal. 14

15 Sunarto,loc. cit

16 Lihat: Maggie Humm, Ensiklopedia Feminisme, Judul asli: Dictionary of Feminist Theories, pentrj. Mundi Rahayu, (Yogya, Fajar Pustaka Baru, 2002), hal. 289-290, dalam Daharmi Astuti, Fatwa Hukum Misoginis (Kritik Khaled Abou elFadl Terhadap Fatwa CRLO di Amerika),
(Pekanbaru, Pusat Studi Wanita UIN Suska Riau, 2008), Jurnal Marwah Vol. II No. 1, hal. 73

17 Sunarto, Op,Cit, hal. 54

18 A.J Wensick, Op,Cit, hal. 128

19 Abi ‘Iysa Muhammad bin 'Iysa bin Saurah, Op, Cit, Juz 4, hal. 357

20 Ibid, Jilid 34, hal. 74

${ }^{21}$ Al-Mitqan Jamaluddin Abi Hajjaj Yusuf alMaziy, Op, Cit, Jilid 10, hal. 446

22 Ibid, Jilid 02, hal. 338

${ }^{23}$ Ibid, Jilid 34, hal. 74

${ }^{24} \mathrm{Ibid}$, Jilid 17, hal. 429

25 Ibid

26 Ibid, Jilid 34, hal. 74

27 Ibid, Jilid 17, hal. 429

28 Ibid, Jilid 34, hal. 74

29 Ibid, Jilid 17, hal. 429

30 Ibid

31 Ibid, Jilid 12, hal. 5

32 Ibid, Jilid 28, hal. 250

33 Ibid, Jilid 25, hal. 581

34 Abi 'Abdillah Muhammad bin Yazid alQazwayniy, Op, Cit, Juz 2, hal. 495

35 Ibid, Jilid 34, hal. 74

36 Ibid, Jilid 02, hal. 338

37 Ibid, Jilid 34, hal. 74

38 Ibid, Jilid 17, hal. 429

39 Ibid

${ }^{40}$ Ibid, Jilid 34, hal. 74

${ }^{41}$ Ibid, Jilid 17, hal. 429

42 Ibid

43 Ibid, Jilid 18, hal. 478

44 Imam al-Hafidz al-'Ula Muhammad 'Abdurrahman Ibnu 'Abdurrahman alMubarakfuri, Tuhfatul Ahwazi bi Syarhi Jami'u Tirmidzi, (Daarul Hadis, 2001), Jilid 7, hal. 203

DAFTAR PUSTAKA

A.J Wensick, Mu'jam al-Mufahras li Alfazh al-Hadits al-Nabawiyah, (Leiden, Maktabah Brill, 1937)

Abi ‘Isa Muhammad bin 'Isa bin Saurah, Sunan Tirmidzi, (Daarul Fikri, t.th)

Alamsyah, Menyikapi Hadis-Hadis Misoginis, (Laboratorium Studi alQur'an), dikutip pada http:// menyikapi-hadis - hadis - 
Nurdin dan Rufika Sari: Misogynist di dalam Hadis (Telaah Hadis Sunan Tirmidzi dan Ibnu Majah, Perempuan Sumber Fitnah Paling Berbahaya)

misoginishtml//: 4-06-2013

Al-Imam al-Hafidz Abi 'Abdillah Muhammad bin Ismail al-Bukhari, (Beirut, Dar Ibn Katsir, 1998), Juz 4

Al-Imam al-Hafidz Abi 'Abdillah Muhammad bin Ismail al-Bukhari, Op,Cit, Kitab Fitan, hadis nomor 7099 juz 4

Anita Masduki, Perempuan dalam Islam: Hadith Misoginis versi Fatima Mernissi, (Voa Islam (Voice of alIslam) Headline News, Bekasi, 2009), diakses pada tanggal 08/ 012014

ArifSubhan dkk, Citra Perempuan dalam Islam Pandangan Ormas Kegamaan, (Jakarta, PT. Gramedia Pustaka Utama, 2003)

Badwi Mahmud al-Syaikh, 100 Pesan Nabi untuk Wanita: Penuntun Akhlak dan Ibadah, (Bandung, PT. Mizan Pustaka, 2009)

Imam al-Hafidz al-`Ula Muhammad 'AbdurrahmanIbnu'Abdurrahman al-Mubarakfuri, Tuhfatul Ahwazi bi Syarhi Jami'u Tirmidzi, (Daarul Hadis, 2001), Jilid 7

Lihat: Maggie Humm, Ensiklopedia Feminisme, Judul asli: Dictionary of Feminist Theories, pentrj. Mundi
Rahayu, (Yogya, Fajar Pustaka Baru, 2002), hal. 289-290, dalam Daharmi Astuti, Fatwa Hukum Misoginis (Kritik Khaled Abou el-Fadl Terhadap Fatwa CRLO di Amerika), (Pekanbaru, Pusat Studi Wanita UIN Suska Riau, 2008), Jurnal Marwah Vol. II No. 1

London School Beyond Borders: Communication Modernit \& History, (STIKOM The London School of Public Relations, Jakarta,The First LSPR Communication Research Conference 2010)

Muhammad Zaki Syech Abubakar, Pengertian Hadis Misoginis (Bagian Pertama), (Lampung, Laboratorium Studi al-Qur'an, 2012), dikutip pada: http://pengertian-hadismisoginis-bagian-pertama, tanggal: 22/05/2013

Muhammad Zaki Syech Abubakar, Pengertian Hadis Misogynist (Bagian Pertama), (Lampung, Jayusman Djusar, Senin 30 Mei 2011), dikutip pada http:// pengertian-hadismisogynisthtml// :12/03/2013

Nurhasanah, Perempuan dalam Kitab Sahih Bukhari (Tela'ah Terhadap Hadits "Penolakan Istri atas Ajakan Suami untuk Melakukan Hubungan Sex"), (Pekanbaru, Pusat Studi Wanita UIN Suska Riau, 2006), 
marwah, Vol. XIII No. 2 Desember Th. 2014

Jurnal Marwah Volume IV, No. 2

Sunarto, Televisi, Kekerasan, dan Perempuan, (Jakarta, PT. Kompas Media Nusantara, 2009)
Yusuf Qardhawi, Hadyul Islam Fatawi Mu'ashirah, (Beirut-Lebanon, Daarul Ma'rifah, 1988), penerjemah. As'ad Yasin, FatwaFatwa Kontemporer, (Jakarta, Gema Insani Press, 1995), Jilid 2 